\title{
Starvation survival in Listeria monocytogenes: characterization of the response and the role of known and novel components
}

\author{
Kevin C. Herbert and Simon J. Foster \\ Author for correspondence: Simon J. Foster. Tel: +44 114 2224411. Fax: +44 1142728697. \\ e-mail: s.foster@sheffield.ac.uk
}

Department of Molecular Biology and Biotechnology, University of Sheffield, Firth Court, Western Bank, Sheffield S10 2TN, UK

\begin{abstract}
The starvation survival response (SSR) of Listeria monocytogenes EGD is induced under glucose- or multiple-nutrient-, but not amino-acid limitation. $0.01-0.2 \%$ of the population remain viable even after $20 \mathrm{~d}$ and the survivors show a reduced cell size and increased cross-protection to several environmental stresses. The development of the SSR may therefore be important in $L$. monocytogenes survival in the food environment. The initiation, but not the maintenance, of the SSR involves both protein and cell wall biosynthesis. It is also likely that nutrients released from dead cells are recycled to allow survival of the remaining population. To define the molecular mechanisms involved in the initiation, maintenance and release from the SSR the role of known, and novel, components was examined. The wellcharacterized regulators SigB and PrfA are both required for the full SSR and effect stress resistance during growth and starvation. A transposon mutagenesis screen identified two novel loci with roles in the SSR and stress resistance. Characterization of the transposon insertion sites revealed a putative homologue of the gene yulB from Bacillus subtilis and a gene of unknown function. The potential individual and combined roles of the SSR components are discussed.
\end{abstract}

Keywords: stress resistance, nutrient limitation, SigB, PrfA

\section{INTRODUCTION}

In the natural environment, fluctuations in the availability of nutrients are common. To cope with lengthy periods of nutrient limitation, bacteria have developed a starvation survival response (SSR). This involves a physiological adaptation to insufficient nutrients for growth. The SSR has been well studied in a number of species including Vibrio spp., Escherichia coli, Salmonella typhimurium and Staphylococcus aureus (Foster \& Spector, 1995; Kjelleberg et al., 1993; Kolter et al., 1993; Watson et al., 1998a).

During starvation, most of the population of $S$. aureus dies; however, the survivors undergo a differentiation process resulting in smaller cells (Watson et al., 1998b). Associated with long-term starvation, many species show an increase in resistance to a number of en-

Abbreviation: SSR, starvation survival response. vironmental stresses such as low $\mathrm{pH}$, heat and oxidative stress (Hartke et al., 1994; Watson et al., 1998a). Development of the SSR is dependent on differential gene expression (Morton \& Oliver, 1994; Reeve et al., 1984), and a number of components important in its development and maintenance have been characterized (Cashel et al., 1996; Hengge-Aronis, 1996; Watson et al., 1998b). Important in the instigation of general stress resistance in Gram-positive bacteria such as Bacillus subtilis, Listeria monocytogenes and S. aureus is the alternative sigma factor SigB, although its role in the SSR is unclear (Becker et al., 1998; Chan et al., 1998; Hecker \& Völker, 1998).

L. monocytogenes is well known as a food-borne pathogen, particularly associated with outbreaks involving dairy and meat products (Farber \& Peterkin, 1991). Infection in humans can occur as bacteraemia, meningitis or disseminated infection, and is especially notable for the high mortality rate it causes in neonates $(10-50 \%)$ (Farber \& Peterkin,1991). The regulation of virulence gene expression is known to occur in response 
to environmental signals, and is governed by the transcriptional activator PrfA (Behari \& Youngman, 1998; Böckmann et al., 1996; Leimeister-Wächter et al., 1992; Mengaud et al., 1991). The bacterium is highly versatile, and can be found in a remarkably wide range of environments, including water, soils, silage, plant surfaces and the human intestinal tract. It is likely that this organism commonly encounters conditions of starvation, and thus the SSR of L. monocytogenes has implications for survival of the bacterium in the environment, in the colonization of food production sites, in the subsequent colonization of food products and in the ability to establish infections. Survival of $L$. monocytogenes has been studied in foodstuffs; however this is typically in relation to food preservation methods (Bolton \& Frank, 1999; Casadei et al., 1998; Gahan et al., 1996). In this work we have characterized the SSR of L. monocytogenes EGD, and have identified the roles of two novel starvation survival loci.

\section{METHODS}

Bacterial strains. Strains of L. monocytogenes used in this study are shown in Table 1 . Strains were routinely maintained on TSB agar (Difco Tryptic Soy Broth with 1.5\%, w/v, Oxoid Agar no. 1), and plates were incubated at $37^{\circ} \mathrm{C}$. Glycerol stocks of strains were kept at $-20^{\circ} \mathrm{C}$ for long-term storage.

Growth and starvation of bacterial strains. L. monocytogenes serovar $1 / 2$ a, strain EGD was grown in glucose-limited chemically defined medium (CDM) unless otherwise stated. CDM was modified from that described by Trivett \& Meyer (1971). The composition of glucose-limited CDM was as follows (per litre): $\mathrm{NaOH}, 0.24 \mathrm{~g}$; nitrilotriacetic acid, $0.48 \mathrm{~g}$; $\mathrm{FeCl}_{3}, 0.048 \mathrm{~g} ; \mathrm{MgSO}_{4} .7 \mathrm{H}_{2} \mathrm{O}, 0.41 \mathrm{~g} ; \mathrm{NH}_{4} \mathrm{Cl}, 1.0 \mathrm{~g} ; \mathrm{K}_{2} \mathrm{HPO}_{4}$, $0.85 \mathrm{~g} ; \mathrm{NaH}_{2} \mathrm{PO}_{4}, 0 \cdot 15 \mathrm{~g}$; MOPS, $4.18 \mathrm{~g}$; L-lysine.HCl, $0.1 \mathrm{~g}$; L-leucine, $0.1 \mathrm{~g}$; DL-isoleucine, $0.2 \mathrm{~g}$; DL-valine, $0.2 \mathrm{~g}$; DLmethionine, $0.2 \mathrm{~g}$; L-arginine, $0 \cdot 2 \mathrm{~g}$; L-histidine, $0.2 \mathrm{~g}$; glucose, $1.0 \mathrm{~g} ; \alpha$-lipoic acid, $10 \mu \mathrm{g}$; biotin, $1 \mathrm{mg}$; thiamin, $5 \mathrm{mg}$; riboflavin, $1 \mathrm{mg}$. The liquid medium was prepared as described by Trivett \& Meyer (1971) excepting: (i) $\mathrm{K}_{2} \mathrm{HPO}_{4}$ and $\mathrm{NH}_{4} \mathrm{Cl}$ were dissolved in only $480 \mathrm{ml}$ distilled water; (ii) $20 \mathrm{ml}$ sterile 1 M MOPS ( $\mathrm{pH} \mathrm{7.5)} \mathrm{solution} \mathrm{was} \mathrm{added} \mathrm{to} \mathrm{the} \mathrm{final}$ medium; (iii) the amino acids were dissolved in $390 \mathrm{ml}$ distilled water.

Glucose- or amino-acid-limited CDM was made by decreasing the glucose concentration from $0.2 \%(\mathrm{w} / \mathrm{v})$ to $0.1 \%$ or reducing the total amino acid concentration from $0.12 \%$ (w/v) to $0.0016 \%$, respectively. Glucose-minus medium was prepared by omitting glucose from the medium.

Starvation cultures were inoculated to an $\mathrm{OD}_{600}$ of $0 \cdot 01$, prepared as previously described (Watson et al., 1998b), incubated with shaking ( 250 r.p.m.) at $37^{\circ} \mathrm{C}$ to stationary phase $(18 \mathrm{~h})$, then incubated statically at 25 or $37^{\circ} \mathrm{C}$. All cultures reached an $\mathrm{OD}_{600}$ of $0 \cdot 65-0.75$, which corresponded to approximately $1 \times 10^{9}$ c.f.u. $\mathrm{ml}^{-1}$. Multiple-nutrient-limited cells were prepared by harvesting stationary-phase CDM cultures $\left(37^{\circ} \mathrm{C}, 18 \mathrm{~h}\right)$ by centrifugation $(4000 \mathrm{~g}$ for $10 \mathrm{~min}$ at room temperature). The cells were washed twice by resuspension and centrifugation with an equal volume of PBS (Sambrook et al., 1989) or distilled water, before being resuspended in PBS or distilled $\mathrm{H}_{2} \mathrm{O}$, respectively, to the original culture volume. Viable counts were determined by serial dilution in PBS, plating on TSB agar and incubation overnight at $37^{\circ} \mathrm{C}$. The minimum detection level was 100 c.f.u. $\mathrm{ml}^{-1}$. Results are mean values of at least two separate experiments, for which the SD was less than $\pm 40 \%$ of the mean.

Electron microscopy. Samples were centrifuged $(10000 \boldsymbol{g}$ for $5 \mathrm{~min}$ at $4{ }^{\circ} \mathrm{C}$ ) and the supernatant removed. The cells were fixed and stained by standard means (Watson et al., 1998b), and sections studied with a Phillips CM-10 transmission electron microscope. Mean values \pm SD were calculated from at least 60 individual cells viewed within a randomly selected area.

Penicillin G. Penicillin G to a final concentration of $20 \mu \mathrm{g} \mathrm{ml} \mathrm{l}^{-1}$ $(20 \times \mathrm{MIC})$ was added to starved cultures incubated at $37^{\circ} \mathrm{C}$. Penicillin G was still biologically active to greater than MIC level after $15 \mathrm{~d}$ incubation at $37^{\circ} \mathrm{C}$ (data not shown). Glucoselimited CDM was used for all penicillin $\mathrm{G}$ experiments.

Chloramphenicol. Synchronous glucose limitation of cultures was achieved by harvesting mid-exponential $\operatorname{OD}_{600} 0 \cdot 3$, $37^{\circ} \mathrm{C}$ ) cells by centrifugation and resuspension in glucoseminus CDM. Chloramphenicol $\left(100 \mu \mathrm{g} \mathrm{ml}^{-1}\right)$ was added after $0,1,2,4,8$ and $24 \mathrm{~h}$ incubation at $37^{\circ} \mathrm{C}$. Control cultures with no chloramphenicol added were also monitored. Viability was determined by plating on TSB agar.

Stress resistance. Mid-exponential-phase and $6 \mathrm{~h}$ postexponential-phase cells grown at $37^{\circ} \mathrm{C}$ were harvested by centrifugation ( $5000 \mathrm{~g}, 3 \mathrm{~min}$, room temperature). Challenge with heat, acid or oxidative stress was carried out as described by Watson et al. (1998a), except that acid resistance was examined in CDM adjusted to $\mathrm{pH} 3.5$ with $\mathrm{HCl}$. Viability was determined by plating on TSB agar.

Table 1. L. monocytogenes strains used in this study

\begin{tabular}{|llcl|}
\hline Strain & Relevant genotype & Parent strain & \multicolumn{1}{c|}{ Source } \\
\hline EGD & Wild-type & - & Wuenscher et al. (1993) \\
LMA2B & sigB, $\mathrm{Km}^{\mathrm{R}}$ & $10403 \mathrm{~S}$ & Becker et al. (1998) \\
DES011 & sigB, Km ${ }^{\mathrm{R}}$ & EGD & This study \\
DES012 & prfA & EGD & C. Dickneite* \\
DES028 (DES029) & yulB $:: \operatorname{Tn} 917$ & EGD & This study \\
DES035 (DES045) & ORF1 : :Tn917 & EGD & This study \\
\hline
\end{tabular}

*Biozentrum, Lehrstuhl für Mikrobiologie, Würzburg, Germany. 
Phage transduction of mutations into wild-type EGD background. Lysates of L. monocytogenes LMA2B carrying a null mutation of the $\operatorname{sig} B$ gene (Becker et al., 1998) and starvationsurvival-defective mutants were prepared using bacteriophage $\phi$ LMUP35 (Hodgson, 2000). Exponential-phase cells of $L$. monocytogenes EGD $\left(1 \times 10^{8}\right.$ c.f.u. $)$ were incubated for 40 min at room temperature with $1 \times 10^{8}$ p.f.u. of phage. The mixture was overlaid onto BHI agar (Difco) plates containing sodium citrate $(10 \mathrm{mM}, \mathrm{pH} 7 \cdot 5)$ and kanamycin $\left(40 \mu \mathrm{g} \mathrm{ml}^{-1}\right)$ using $3 \mathrm{ml}$ BHI with $0.75 \%$ (w/v) agar. For selection using erythromycin, the mixture was overlaid onto $\mathrm{BHI}$ agar plates containing sodium citrate $(10 \mathrm{mM}, \mathrm{pH} 7 \cdot 5)$ and erythromycin $\left(1.5 \mu \mathrm{g} \mathrm{ml} \mathrm{m}^{-1}\right)$ and incubated for $2 \mathrm{~h}$ at $37^{\circ} \mathrm{C}$. The plates were then overlaid with $3 \mathrm{ml} \mathrm{BHI}$ with $0.75 \%(\mathrm{w} / \mathrm{v})$ agar and $15 \mu \mathrm{g}$ erythromycin $\mathrm{ml}^{-1}$. Transductants were selected after the plates had been incubated overnight at $37^{\circ} \mathrm{C}$.

Catalase activity during growth of $L$. monocytogenes EGD. Cells from a $1 \mathrm{ml}$ sample of culture were harvested by centrifugation $(14000 \mathrm{~g}, 2 \mathrm{~min})$, and incubated in $2.5 \mathrm{mg}$ lysozyme $\mathrm{ml}^{-1}$ dissolved in Kpi buffer $\left(0.615 \mathrm{M} \mathrm{K}_{2} \mathrm{HPO}_{4}\right.$ and $0.385 \mathrm{M} \mathrm{KH}_{2} \mathrm{PO}_{4}$ in distilled $\mathrm{H}_{2} \mathrm{O}$ ) at $37^{\circ} \mathrm{C}$ for $30 \mathrm{~min}$. Catalase activity was determined by decrease in $\mathrm{H}_{2} \mathrm{O}_{2}$ concentration (Beers \& Sizer, 1952) in Kpi buffer ( $\mathrm{pH} 7 \cdot 0$, $25^{\circ} \mathrm{C}$ ) using a Shimadzu UV-2401 PC spectrophotometer. Protein concentration was determined colorimetrically (BioRad protein assay reagent), using BSA as standard.

Tn917-LTV3 insertion libraries. Two libraries of Tn917-LTV3 transposon insertional mutants were created using the temperature-sensitive vector pLTV3 as previously described by Camilli et al. (1990), with the exception that the cells were grown through three subcultures at $40.5{ }^{\circ} \mathrm{C}$ in $\mathrm{BHI}$ containing $5 \mu \mathrm{g}$ erythromycin $\mathrm{ml}^{-1}$. The libraries both contained approximately $2 \times 10^{10}$ c.f.u. $\mathrm{ml}^{-1}$ and over $90 \%$ of the cells contained transposon insertions.

Starvation survival mutant selection. A library of transposon mutants was screened as described by Watson et al. (1998b), with the exceptions that the glucose-limited CDM agar described above was used and the screen was conducted at $37^{\circ} \mathrm{C}$ over $12 \mathrm{~d}$.

Molecular biological methods. All molecular biological methods were performed as described by Sambrook et al. (1989). Chromosomal DNA was isolated using the QIAGEN $100 / \mathrm{G}$ kit as directed in the manufacturer's manual.

Nucleotide sequence analysis. DNA sequence was obtained directly from purified chromosomal DNA using an ABI BigDye sequencing kit and an ABI 373A DNA sequencer (Applied Biosystems). A 19 bp oligonucleotide (5'-CTCACAATAGAGAGATGTCACCGTC-3') complementary to the lacZ-proximal end of the transposon was used as sequencing primer. Homology searches were performed using the BLAST search program at the National Centre for Biotechnology Information database (Bethesda, USA).

\section{RESULTS}

\section{Establishment of defined starvation survival conditions}

To examine the SSR a defined medium for growth of $L$. monocytogenes was determined, based on that described by Trivett \& Meyer (1971). Limitation for specific components was carried out as described in Methods. Glucose-limited cultures showed a fall of $90-99 \cdot 9 \%$ in

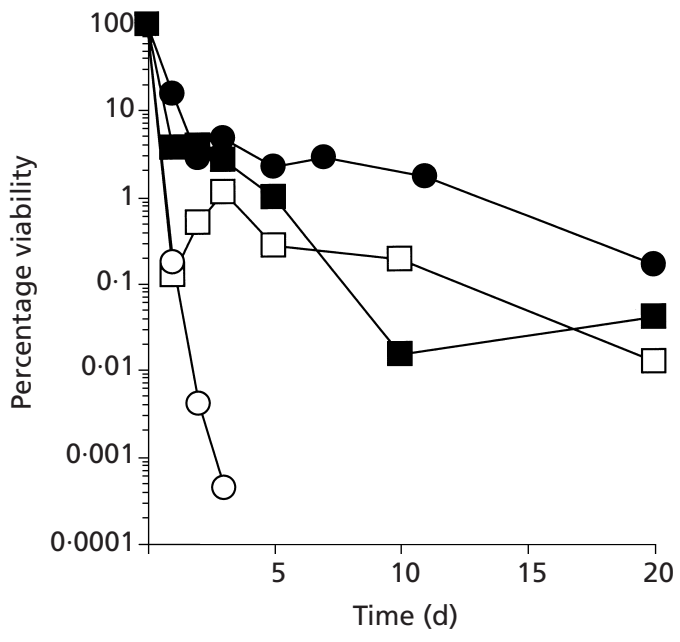

Fig. 1. Survival of L. monocytogenes EGD at $37^{\circ} \mathrm{C}$. Cells were incubated in glucose-limited CDM (O), amino-acid-limited CDM $(\bigcirc)$, PBS ( $\square$ ) or distilled $\mathrm{H}_{2} \mathrm{O}(\square)$. Viability was determined by plating on TSB agar. The initial concentration was approximately $1 \times 10^{9}$ c.f.u. $\mathrm{ml}^{-1}$.

the viable population over the first $2 \mathrm{~d}$. From day 2 onwards, however, there was a significant drop in the rate of fall of viability, with long-term culture viability being retained (Fig. 1). Multiple nutrient limitation elicited by resuspension in PBS or distilled $\mathrm{H}_{2} \mathrm{O}$ also resulted in starvation survival (Fig. 1). This was independent of whether the cultures were grown in glucose- or amino-acid-limited medium. In contrast, the viability of cultures incubated in amino-acid-limited $\mathrm{CDM}$ at $37^{\circ} \mathrm{C}$ declined rapidly, becoming undetectable within $5 \mathrm{~d}$ (Fig. 1). A temperature-dependent survival response was seen in glucose-limited cultures, as a higher percentage of the original population was retained after $20 \mathrm{~d}$ at $25^{\circ} \mathrm{C}$ compared to $37^{\circ} \mathrm{C}(2 \cdot 4 \%$ and $0.16 \%$, respectively; data not shown), although the initial rate of drop in viability was unchanged.

\section{Effect of cell density on starvation survival}

Cell density during the SSR may be important as it determines the total potential nutrients available to the population, release of which will require the death of a proportion of the cells. Cells from a $6 \mathrm{~h}$ post-exponential-phase glucose-limited culture were harvested by centrifugation and resuspended in water, or the spent culture medium in which they had been grown, at a range of initial cell densities. Upon resuspension in water, survival was seen to be densitydependent as the cells became unculturable within $3 \mathrm{~d}$ if resuspended at $2 \times 10^{8}$ c.f.u. $\mathrm{ml}^{-1}$ (Fig. 2), but unculturable within $24 \mathrm{~h}$ when resuspended at $1 \times 10^{7}$ c.f.u. $\mathrm{ml}^{-1}$ or below (data not shown). When resuspended in spent culture supernatant at initial densities of between $7 \times 10^{5}$ and $1 \times 10^{9}$ c.f.u. $\mathrm{ml}^{-1}$, viability in all cultures was retained at approximately 


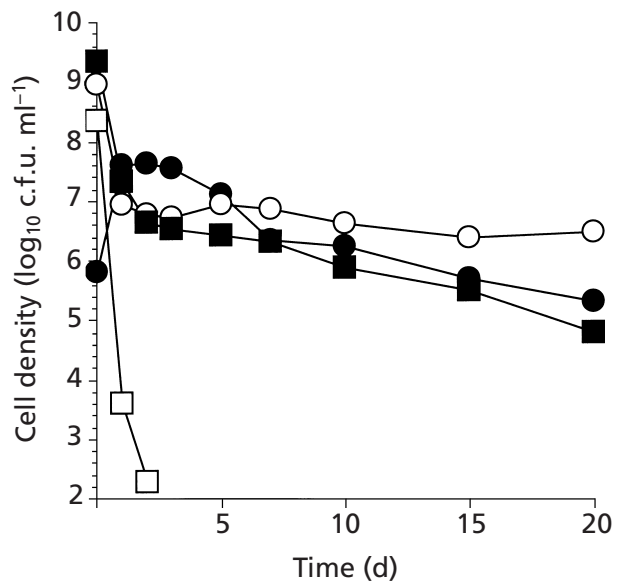

Fig. 2. Effect of cell density on survival of $L$. monocytogenes EGD at $37{ }^{\circ} \mathrm{C}$. Starvation cultures were prepared as described in Methods and harvested as described (Watson et al., 1998a). Cells were resuspended in filter-sterilized culture supernatant to $7 \times 10^{5}$ c.f.u. $\mathrm{ml}^{-1}(\mathbf{O})$ and $1 \times 10^{9}$ c.f.u. $\mathrm{ml}^{-1}(\bigcirc)$, and in water to $2 \times 10^{9}$ c.f.u. $\mathrm{ml}^{-1}(\boldsymbol{\square})$ and $2 \times 10^{8}$ c.f.u. $\mathrm{ml}^{-1}(\square)$. Viability was determined by plating on TSB agar.

$5 \times 10^{5}-5 \times 10^{6}$ c.f.u. $\mathrm{ml}^{-1}$ by $20 \mathrm{~d}$ (Fig. 2 ). The survival of cells taken from long-term ( $7 \mathrm{~d}$ ) glucose-limited cultures was also density-dependent when incubated in water, all viability being lost within $7 \mathrm{~d}$ if resuspended at $2 \times 10^{5}$ c.f.u. $\mathrm{ml}^{-1}$ or below (data not shown). Longterm-starved cells resuspended in spent culture supernatant resulted in cell viability of approximately $5 \times 10^{6}$ c.f.u. $\mathrm{ml}^{-1}$ after $20 \mathrm{~d}$ irrespective of initial cell density between $4 \times 10^{3}$ and $5 \times 10^{6}$ c.f.u. $\mathrm{ml}^{-1}$. This implies the presence of a significant level of nutrients within the medium capable of sustaining cellular viability (data not shown).

\section{Effect of starvation on cell morphology}

To determine if the SSR results in an altered cellular morphology, as has been observed in other species, cells from $7 \mathrm{~d}$ glucose- and amino-acid-limited cultures were observed by electron microscopy in comparison to cells from an exponentially growing culture (data not shown). It was noted that there was large variation of cell length in both exponential-phase and long-termstarved cells. In $7 \mathrm{~d}$ glucose-limited cultures, the mean cell length was significantly reduced $(P<0 \cdot 01$; Student's $t$-test) with a mean cell length of $1 \cdot 00 \pm 0 \cdot 26 \mu \mathrm{m}$, compared to $1 \cdot 29 \pm 0 \cdot 29 \mu \mathrm{m}$ in exponential growth. The mean cell width was also significantly changed $(P<0 \cdot 01$; Student's $t$-test), increasing from $0.41 \pm 0.03 \mu \mathrm{m}$ in exponential-phase cells to $0.46 \pm 0.05 \mu \mathrm{m}$ in the glucoselimited cultures. The occurrence of partial division septa was significantly reduced in the long-term glucoselimited cultures, with only $17 \%$ seen to possess partial septa compared to $30 \%$ of exponential-phase cells. It was noted that large numbers of 'ghost' cells were present in the glucose-limited culture, indicating that

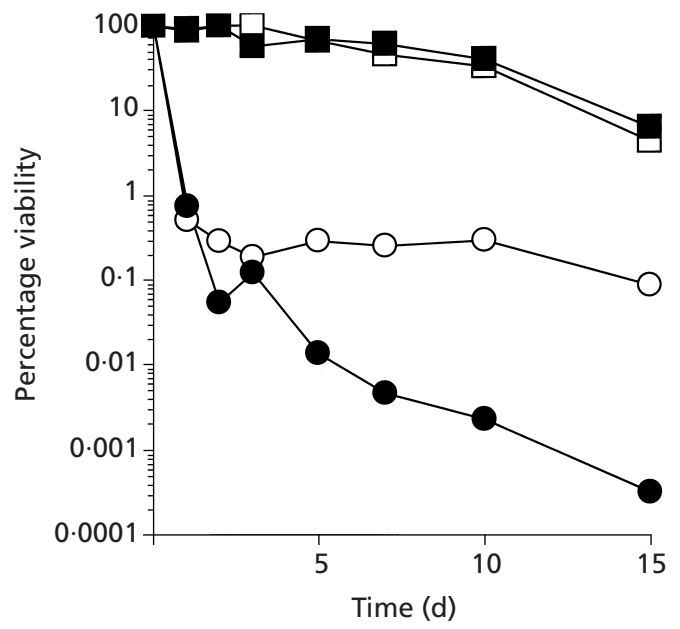

Fig. 3. Effect of penicillin $G$ treatment on survival in glucoselimited CDM. Post-exponential-phase $(0, \bigcirc)$ and $7 \mathrm{~d}$ glucosestarved $(\boldsymbol{\square}, \square)$ L. monocytogenes EGD cultures were incubated at $37^{\circ} \mathrm{C}$ with $(\mathbf{O}, \mathbf{\square})$ or without $(O, \square)$ penicillin $\mathrm{G}$ $\left(20 \mu \mathrm{g} \mathrm{ml}^{-1}\right)$. Changes in viability were determined by plating on TSB agar. The initial concentration was approximately $1 \times 10^{9}$ c.f.u. $\mathrm{ml}^{-1}$, except for $7 \mathrm{~d}$ glucose-starved cultures $\left(5 \times 10^{6}\right.$ c.f.u. $\left.\mathrm{ml}^{-1}\right)$.

cell lysis may be significant. In amino-acid-limited cultures, very few, apparently intact, bacteria were found. The 'cells' observed in these cultures possessed electron-dense fragmented cell walls, with no apparent change in cell dimensions compared to vegetative cells.

\section{Role of cell wall biosynthesis during starvation survival}

Penicillin G kills actively growing and dividing cells and so can be used to determine the division status of the population. The addition of penicillin $G$ to $6 \mathrm{~h}$ postexponential-phase cultures increased the rate of loss of viability compared to the control cultures (Fig. 3). After an initial fall of $99 \%$ in viability over the first $2 \mathrm{~d}$, similar to that in the controls, viability continued to fall steadily past the point where that of the control cultures stabilized at about $0 \cdot 2 \%$ of the original population (Fig. 3 ). When penicillin $\mathrm{G}$ was added to $7 \mathrm{~d}$ glucose-limited cultures, no effect was seen compared to the untreated control (Fig. 3).

\section{Role of protein synthesis during starvation survival}

To determine whether continued protein synthesis is required for starvation survival, chloramphenicol $\left(100 \mu \mathrm{g} \mathrm{ml}^{-1}\right)$ was added at different times during starvation. At $37^{\circ} \mathrm{C}$, protein synthesis inhibition up to $4 \mathrm{~h}$ after initiation of glucose limitation resulted in viability becoming undetectable by $10 \mathrm{~d}$, whereas addition of chloramphenicol $8 \mathrm{~h}$ post-starvation no longer had an effect on survival for up to $50 \mathrm{~d}$ (data not shown). 

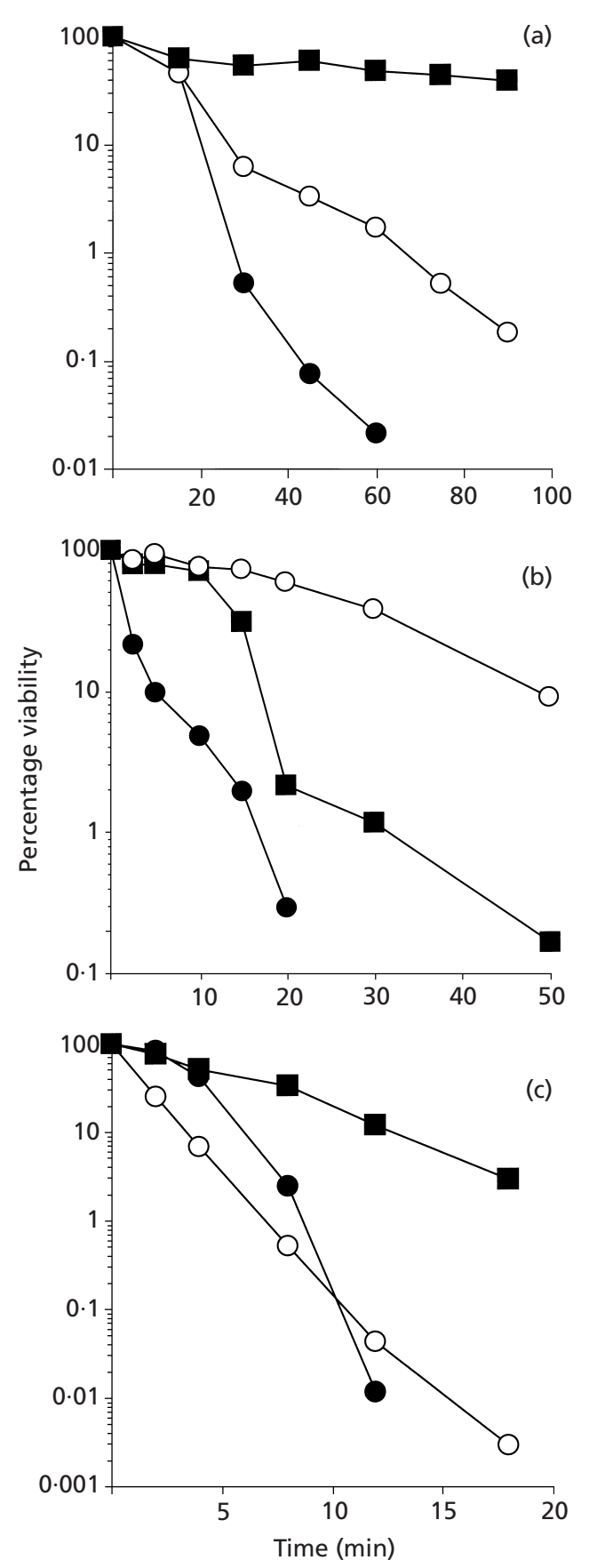

Fig. 4. Resistance of exponential-phase (0), $6 \mathrm{~h}$ postexponential-phase $(O)$ and $7 \mathrm{~d}$ glucose-starved $(\boldsymbol{D}) \mathrm{L}$. monocytogenes EGD cells. Cells were resuspended in PBS at an initial concentration of $5 \times 10^{6}$ c.f.u. $\mathrm{ml}^{-1}$. Viability was determined after exposure to $\mathrm{pH} 3.5$ (a), $7.5 \mathrm{mM} \mathrm{H}_{2} \mathrm{O}_{2}$ (b) or heat stress at $55^{\circ} \mathrm{C}$ (c) by plating on TSB agar.

\section{Starvation-induced stress resistance}

The effects of exposure to heat $\left(55^{\circ} \mathrm{C}\right)$, low $\mathrm{pH}(\mathrm{pH} 3 \cdot 5)$ and oxidative stress $\left(7 \cdot 5 \mathrm{mM} \mathrm{H}_{2} \mathrm{O}_{2}\right)$ were tested on cells at different growth phases in glucose-limited cultures (exponential phase, $6 \mathrm{~h}$ post-exponential phase and 7-dstarved) (Fig. 4). As the age of the cultures increased, the

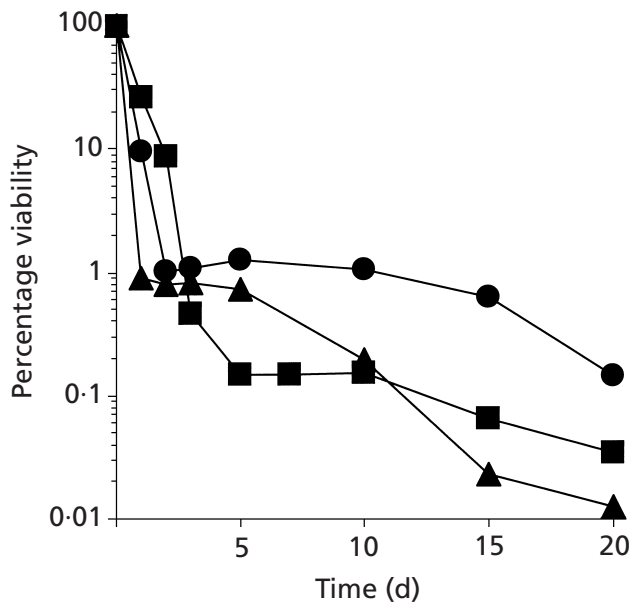

Fig. 5. Survival of L. monocytogenes EGD (wild-type; DES011 (sigB; $\boldsymbol{\Delta})$ and DES012 (prfA; $\boldsymbol{\square})$ in glucose-limited CDM at $37^{\circ} \mathrm{C}$. Viability was determined by plating on TSB agar. The initial concentration was approximately $1 \times 10^{9}$ c.f.u. $\mathrm{ml}^{-1}$.

cells developed a much greater level of resistance to acid (Fig. 4a) and heat stress (Fig. 4c). In fact 7-d-starved cells were over 1000-fold more resistant after exposure to acid or heat (for 60 and $12 \mathrm{~min}$, respectively) compared to exponential-phase cells. $\mathrm{H}_{2} \mathrm{O}_{2}$ resistance increased during post-exponential phase, and then fell during long-term starvation (Fig. 4b). Resistance to oxidative stress was significantly increased if the cells were retained in the original culture supernatant. Approximately $10 \%$ of exponential-phase cells remained viable after $90 \mathrm{~min}$, whilst cells from $6 \mathrm{~h}$ post-exponentialphase and $7 \mathrm{~d}$ glucose-limited cultures were totally resistant (data not shown).

\section{The role of known regulatory elements in starvation survival and stress resistance}

The alternative sigma factor, $\operatorname{SigB}$, is known to be involved in stress resistance during vegetative growth of L. monocytogenes (Becker et al., 1998). To determine the role of SigB in the SSR, the sigB null mutation from strain LMA2B was transferred into the EGD background by phage transduction to give strain DES011, and verified by Southern blotting (data not shown). During a starvation survival assay in glucose-limited CDM, DES011 showed the same biphasic kinetics as EGD over the first $5 \mathrm{~d}$, but by $20 \mathrm{~d}$ the $\operatorname{sig} B$ mutant had undergone a 10-fold greater drop in viability (Fig. 5). It was also noted that the $\mathrm{pH}$ in both EGD and DES011 cultures fell only slightly from a value of $7 \cdot 0$ at the start of incubation to between 6.0 and 6.5 after $20 \mathrm{~d}$. The same changes in cell length and the reduction in the occurrence of partial division septa were observed in DES011 $(\operatorname{sig} B)$ during the transition into long-term starvation survival as seen in the parental strain EGD (data not shown).

Exponential-phase cells of DES011 were more sensitive to acid treatment than EGD $(0.02$ and $1 \%$ survival after 


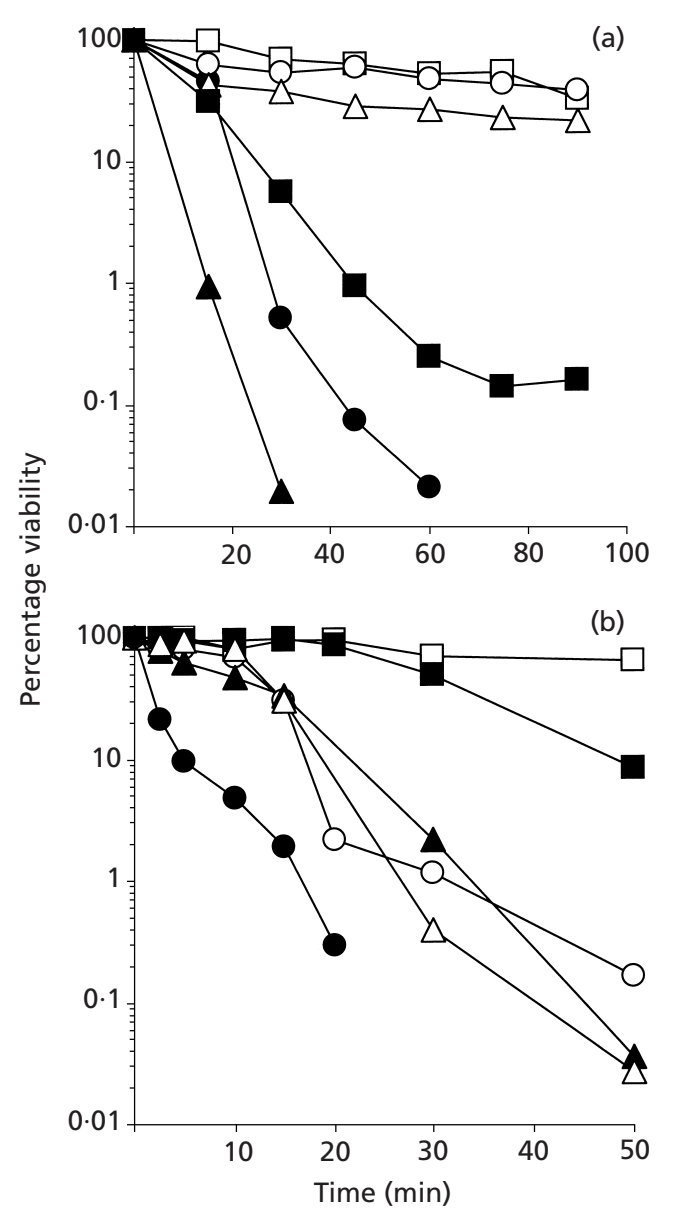

Fig. 6. Resistance of exponential-phase $(\boldsymbol{\theta}, \boldsymbol{\Delta}, \boldsymbol{\square})$ and longterm-starved ( $O, \triangle, \square)$ L. monocytogenes EGD (wild-type; - O), DES011 (sigB; $\Delta, \triangle$ ) and DES012 (prfA; $\square, \square$ ) cells. Viability was determined after exposure to $\mathrm{pH} 3.5$ (a) or $7.5 \mathrm{mM}$ $\mathrm{H}_{2} \mathrm{O}_{2}$ (b). The initial concentration was $5 \times 10^{6}$ c.f.u. $\mathrm{ml}^{-1}$.

25 min, respectively); however, starved cells of both DES011 and EGD were highly acid-resistant (Fig. 6a). The $\operatorname{sig} B$ mutation had no significant effect on the resistance of exponential-phase and 7-d-glucose-limited cultures to incubation at $55^{\circ} \mathrm{C}$ (data not shown). No change in the resistance of DES011 to $\mathrm{H}_{2} \mathrm{O}_{2}$ was found during post-exponential phase or long-term starvation (Fig. 6b, and data not shown). In exponential phase, however, DES011 exhibited greater $\mathrm{H}_{2} \mathrm{O}_{2}$ resistance compared to corresponding EGD cells $(50$ and $1 \%$ survival, respectively, after $15 \mathrm{~min}$ ) (Fig. 6b).

PrfA is a major regulator of virulence determinant production in L. monocytogenes and may have a role in other cellular functions (Ripio et al., 1998). The starvation and stress resistance phenotypes of a prfA deletion mutant in an EGD background (DES012) were studied. DES012 (prfA) shows a consistent reduction in survival during starvation of approximately 10 -fold compared to EGD (Fig. 5). It was also noted that DES012 exhibits a 'small colony variant' phenotype on recovery after long-term starvation. However, the same changes in cell length and the reduction in the occurrence

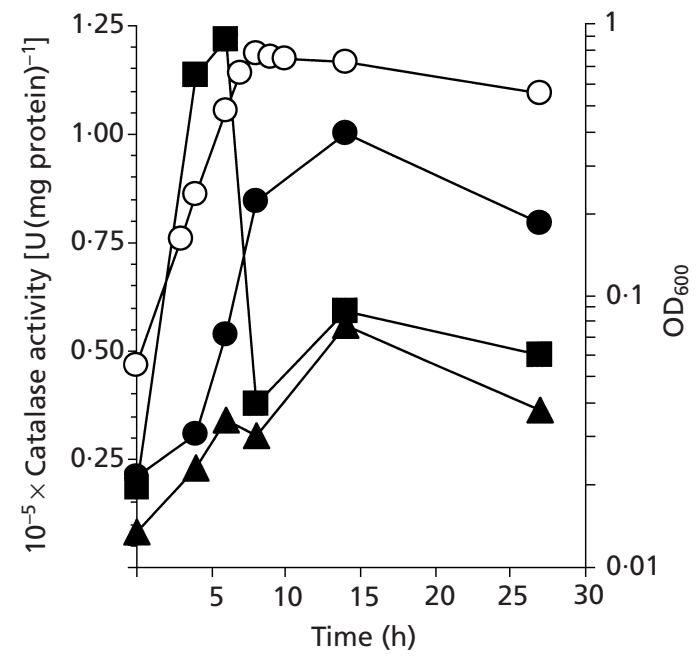

Fig. 7. Catalase activity of $L$. monocytogenes EGD (wildtype; O), DES011 (sigB; $\boldsymbol{\Delta}$ ) and DES012 (prfA; $\boldsymbol{\square})$. Growth $\left(\mathrm{OD}_{600}\right)$ of EGD $(O)$ is also shown. One unit of catalase activity equals the degradation of $1 \mu \mathrm{mol} \mathrm{H}_{2} \mathrm{O}_{2} \mathrm{~min}^{-1}$.

of partial division septa occur in DES012 (prfA) during the transition into long-term starvation survival as seen in the parental strain EGD (data not shown). The prfA deletion had no effect on resistance to heat stress in comparison to the parental strain (data not shown). Exponential-phase cells of DES012 showed 10-fold more resistance to acid treatment after $60 \mathrm{~min}$, whilst starved cells of EGD and DES012 were equally resistant (Fig. 6a). Increased resistance of DES012 to $\mathrm{H}_{2} \mathrm{O}_{2}$ was also observed. Exponential-phase cells were almost fully resistant to $7.5 \mathrm{mM} \mathrm{H}_{2} \mathrm{O}_{2}$, with less than a $1 \log$ fall after 50 min (Fig. 6b), whereas EGD became unrecoverable ( $>10^{3}$-fold loss after $20 \mathrm{~min}$ ) during the experiment. In cells taken from $7 \mathrm{~d}$ glucose-limited cultures, total resistance to $\mathrm{H}_{2} \mathrm{O}_{2}$ was seen compared to a $3 \log$ reduction in viability in EGD cells.

\section{Catalase activity during growth of $L$. monocytogenes EGD}

Catalase is a major factor involved in the resistance of cells to oxidative stress, via degradation of hydrogen peroxide. Catalase activity increased steadily during growth of L. monocytogenes EGD to a maximum level in stationary phase $\left[1 \times 10^{5} \mathrm{U}(\mathrm{mg} \text { protein })^{-1}\right]$ (Fig. 7). The pattern of catalase activity development in the $\operatorname{sig} B$ mutant during growth was the same as in EGD; however the levels observed were consistently reduced by up to $64 \%$ (8 h, Fig. 7). During mid- to late-exponential phase, catalase activity in the prfA mutant increased to over 3.5 times that seen in EGD, reaching a peak after $8 \mathrm{~h}\left[1.2 \times 10^{5} \mathrm{U}(\mathrm{mg} \text { protein })^{-1}\right]$. Activity then fell on entry to stationary phase to levels approximately $50 \%$ of wild-type levels (Fig. 7). In all three strains, during long-term starvation the cells retain relatively low levels of catalase activity $\left[4.9 \times 10^{3}-1.5 \times 10^{4} \mathrm{U}(\mathrm{mg} \text { protein })^{-1}\right]$ (data not shown). 


\section{Isolation of starvation survival mutants}

To identify further components of the SSR two libraries of Tn917-LTV3 transposon insertional mutants were created using the temperature-sensitive vector pLTV3 (Camilli et al., 1990). These libraries were screened for mutants defective in starvation survival under glucoselimited conditions. Of 9000 clones screened, 21 were found to be starvation survival mutants in the agar plate screen. After phage transduction, four clones were found to exhibit a starvation survival defect on solid media. The defect was linked to the Tn917 insertion (five out of five transductants). There was no recovery of the bacterium upon replica plating $\left(24 \mathrm{~h}, 37^{\circ} \mathrm{C}\right)$ from glucose-limited CDM agar plates after $12 \mathrm{~d}$ incubation at $37^{\circ} \mathrm{C}$.

\section{Analysis of Tn917-LTV3 insertion in starvation survival mutants}

Southern hybridization analysis of the mutants revealed that all contained a single transposon (data not shown). DNA sequencing directly from genomic DNA of the mutants revealed that the four clones were two pairs of siblings. The transposon insertion in DES028 and DES029 was found to be located 129 bp downstream of the putative start site of the coding sequence for a homologue of the B. subtilis gene yulB [D70014;39\% identity (17/43 amino acids)]. DES035 and DES045 were found to have the transposon insertion $69 \mathrm{bp}$ downstream of the putative start site in the coding sequence for a gene (ORF1) whose product had no significant homology to any proteins in the database.

\section{Stress resistance of starvation survival mutants}

DES028 and DES045 were chosen as representative of the sibling pairs. When DES028 was incubated at $55^{\circ} \mathrm{C}$, long-term (7 d) glucose-starved cells exhibited a 40 -fold reduction in resistance compared to EGD (12 min, data not shown), whilst the same cells were over 30-fold less resistant to $7.5 \mathrm{mM} \mathrm{H}_{2} \mathrm{O}_{2}$ than EGD $(50 \mathrm{~min}$, data not shown). DES045 cells showed no significant change in starvation-associated stress resistance compared to wild-type cells.

\section{DISCUSSION}

In the chemically defined medium described here, $L$. monocytogenes develops an SSR in reaction to glucoseor multiple-nutrient limitation, enabling maintenance of viability for prolonged periods. The specificity of the generation of the SSR via carbon- or multiple-nutrient limitation equals that of Vibrio sp. and $S$. aureus (Nyström et al., 1992; Watson et al., 1998a).

The development of the SSR is characterized by a rapid fall in viability of $90-99.9 \%$, prior to the long-term maintenance of cell viability. This phenomenon occurs in S. aureus, E. coli and Salmonella typhimurium (Siegele et al., 1993; Spector \& Cubitt, 1992; Watson et al., 1998a), and is proposed to be the result of cryptic growth - the maintenance of a small population of cells via the release of utilizable nutrients from the death and lysis of the majority. Survival kinetics similar to those seen with multiple-nutrient limitation in this report have been found in L. monocytogenes Scott A when stored in phosphate buffer (Lou \& Yousef, 1996). Establishment of the SSR was found to be cell-density-dependent and so cell death-be it via nutrient limitation and/or osmotic stress - and the subsequent release of nutrients, and possibly also signalling molecules, is required for the maintenance of the long-term viability of the remaining cells. This supports the idea of cryptic growth in these cultures. Further evidence is provided by the fact that spent culture supernatant allows the regrowth of cells resuspended at low cell densities to a consistent concentration.

During prolonged glucose starvation, cells of a number of species undergo a series of morphological changes. In E. coli, the RpoS-regulated bolA gene is responsible for the starvation-induced reduction in cell length (Aldea $e t$ al., 1998; Lange \& Hengge-Aronis, 1991). Here, we have shown that L. monocytogenes most likely undergoes reductive division during starvation, resulting in shorter cells. Similar reduction in cell dimensions is also witnessed in $S$. aureus and Micrococcus luteus (Mukamolova et al., 1995; Watson et al., 1998a); however the molecular basis for this in the Grampositive bacteria is unknown.

If the population is undergoing cell division then active peptidoglycan biosynthesis must be occurring, rendering them sensitive to the action of penicillin G. In the early stages of starvation, penicillin $G$ has a deleterious effect on viability, which suggests active division is still occurring. However, after $7 \mathrm{~d}$ no further effects are seen, and so perhaps by this stage the population has reached stasis with no further cell division. In L. monocytogenes, starvation survival is dependent on gross protein synthesis. This correlates with E. coli and S. aureus (Reeve et al., 1984; Watson et al., 1998a) as the cells synthesize novel proteins in response to starvation conditions. Interestingly, it appears that L. monocytogenes no longer synthesizes proteins by $8 \mathrm{~h}$ into starvation as the addition of chloramphenicol has no effect on viability. However, the possibility cannot be ruled out that by this stage the organism has a phenotypic tolerance to chloramphenicol.

In other organisms, many of the differentially expressed proteins have been identified, and several have been found to regulate or confer resistance to environmental stresses (Matin, 1991). An increase in cross-resistance to several stresses has been found to occur as cells become starved (Jenkins et al., 1988; Seymour et al., 1996; Watson et al., 1998a). L. monocytogenes EGD also shows a starvation-associated increase in resistance to environmental stress. Resistance to $\mathrm{H}_{2} \mathrm{O}_{2}$ is probably primarily mediated by an extracellular catalase, which is produced throughout growth. Oxidative damage is a major contributor to cell death and ageing in starved cultures (Dukan \& Nyström, 1998; Nyström, 1999), and may also occur as a result of treatment with 
acid (Clements et al., 1999). The effect of culture supernatant from aged cultures in increasing the apparent resistance of L. monocytogenes EGD cells to $\mathrm{H}_{2} \mathrm{O}_{2}$ is most likely via the protective action of a catalase secreted into the medium, an effect also seen in both $S$. aureus and B. subtilis (Leimeister-Wächter et al., 1992; Watson et al., 1998a).

The increase in heat resistance during starvation supports previous findings on the effect of nutrient stress on thermotolerance (Lou \& Yousef, 1996). It is known that exposure of $L$. monocytogenes to heat shock increases the expression of at least 14 proteins, including GroEL and DnaK (Hanawa et al., 1995). B. subtilis possesses at least four distinct classes of heat-induced proteins regulated by distinct mechanisms : class I (HrcA repressor-dependent), class II (SigB-dependent), class III (CtsR-dependent) and class IV (whose mode of regulation is unknown) (Derré et al., 1999). Studies to date provide evidence that $L$. monocytogenes has the elements of at least three of the classes found in $B$. subtilis (Derré et al., 1999; O'Driscoll et al., 1996; Wiedmann et al., 1998).

The regulation of the SSR is complex and not well understood in Gram-positive bacteria. In E. coli and other Gram-negatives, the alternative sigma factor RpoS has a central role; however this component is absent in Gram-positives. In $B$. subtilis, the alternative sigma factor SigB has been recognized as a general stress response regulator (Völker et al., 1999), controlling a regulon of over 50 genes (Antelmann et al., 1997; Bernhardt et al., 1997). SigB has also been found in other Gram-positives, including S. aureus and L. monocytogenes (Kullik \& Giachino, 1997; Wiedmann et al., 1998). Expression of $\operatorname{sig} B$ in L. monocytogenes was found to increase in response to hydrogen peroxide, acid and temperature shock, increased osmolarity and addition of EDTA (Becker et al., 1998), and a sigB mutant had reduced acid resistance in stationary phase, but unchanged virulence (Wiedmann et al., 1998). Previous work in our laboratory has shown SigB not to have a major role in starvation survival in $S$. aureus (Chan et al., 1998). In L. monocytogenes EGD, however, SigB seems to contribute to starvation survival as the mutant DES011 shows a 10-fold reduction in number of survivors. Low $\mathrm{pH}$ is unlikely to be the principal cause of the reduced survival of DES011, though the possibility remains that the cumulative effect of the slightly reduced $\mathrm{pH}$ over a prolonged period could be sufficient to produce the phenotype seen. Although SigB is partially responsible for acid resistance during exponential and post-exponential phase, it has no role in the high-level resistance seen in long-term-starved cells. This is equivalent to that seen in S. aureus (Chan et al., 1998). Therefore, there are at least two mechanisms of acid resistance in L. monocytogenes EGD - one SigB-dependent, and one starvation-associated, SigB-independent. Acid tolerance is important for L. monocytogenes as mutants with increased resistance are also more virulent (O’Driscoll et al., 1996). Bacterial acid resistance also has implications in food hygiene, as the aforementioned acid-tolerant mutants show increased survival potential in a variety of foodstuffs (Gahan et al., 1996). In L. monocytogenes, we have found that a SigB mutation results in increased $\mathrm{H}_{2} \mathrm{O}_{2}$ resistance, but only during exponential phase. This seems to be independent of catalase expression, and only occurs in washed cells. The molecular basis for this phenomenon is unknown. In $\mathrm{S}$. aureus, $\mathrm{SigB}$ regulates $\mathrm{H}_{2} \mathrm{O}_{2}$ resistance during both exponential phase and starvation survival (Chan et al., 1998).

Another important regulator of gene expression in $L$. monocytogenes is PrfA. This transcriptional activator regulates the production of the major virulence gene cluster in L. monocytogenes in response to environmental signals (temperature, growth phase, iron concentration and $\mathrm{pH}$ ) in association with an unknown cofactor (Behari \& Youngman, 1998; Böckmann et al., 1996; Leimeister-Wächter et al., 1992; Mengaud et al., 1991). PrfA is well known as a homologue of the global regulators Crp and Fnr (Lampidis et al., 1994), and recently the potential role of PrfA in regulating other cellular functions has come to light with the discovery that PrfA negatively regulates ClpC expression (Ripio et al., 1998). ClpC, a member of the Clp ATPase stress protein family, is also known to have a dual role in stress resistance and virulence, with mutants found to be sensitive to iron limitation, increased osmolarity and heat stress, coupled with reduced virulence in vivo (Rouquette et al., 1996). Here we have shown that PrfA contributes not only to starvation survival but also to stress resistance. In fact PrfA seems to down-regulate stress resistance mechanisms during exponential growth. This is likely to be due to PrfA being a member of the complex interacting hierarchy of gene regulators which control the physiology of L. monocytogenes in response to environmental stimuli.

Catalase activity in L. monocytogenes is known to be induced by stresses, namely heat, hydrogen peroxide and salt (Dallmier \& Martin, 1998, 1990). Here, catalase activity in L. monocytogenes EGD was shown to be at least partially controlled by SigB, and thus the situation correlates with that in B. subtilis, where SigB-dependent expression of $k a t E$ forms part of a non-specific oxidative stress response (Engelmann \& Hecker, 1996). The fact that a PrfA deletion mutation changes the temporal expression of catalase activity highlights a further example of stress gene regulation and indicates a possible extended role of PrfA into the basic physiology of L. monocytogenes. It remains to be seen, however, whether this phenomenon results from the direct action of PrfA.

A number of cellular components have been identified with a role in the initiation and maintenance of starvation survival (Watson et al., 1998b). Here, we have identified two novel loci involved in starvation survival under glucose limitation, to our knowledge the first report of such mutants of L. monocytogenes. The insertional mutation in DES028 (DES029) occurred within a homologue of the $y u l B$ gene from B. subtilis, the 
gene product of which is a member of the DeoR family of transcriptional regulators. Notably, the majority of these proteins act as activators or repressors of genes involved in sugar utilization (Beck von Bodman et al., 1992). The ability to use alternative carbon sources is of great importance for cell survival when the initial source of glucose is depleted, and mutations within the complex regulatory pathways would be likely to have a deleterious effect on survival. The inability to recycle those carbon sources released during the death and lysis of the majority of cells in the culture may well cause the defect seen in DES028 (DES029). The reduction in resistance to hydrogen peroxide and heat resistance that is also observed during post-exponential phase and long-term starvation may therefore be a result of the mutant being unable to meet the energy requirements needed to resist these stresses. In strain DES035 (DES045), the Tn917 insertion occurred in a gene, the product of which had no significant homology to known proteins. Therefore, a role for this gene in starvation survival cannot yet be determined.

We have shown that L. monocytogenes has an SSR that results in increased resistance to environmental stresses, and that a number of genes play a role in the starvation survival of L. monocytogenes. This highlights the need to further understand the SSR, as in this state $L$. monocytogenes is highly resistant to environmental stress and so is more difficult to eradicate.

\section{ACKNOWLEDGEMENTS}

We wish to thank A. K. Benson (University of Nebraska, USA) for supplying L. monocytogenes LMA2B, C. Dickneite (Biozentrum, Lehrstuhl für Mikrobiologie, Würzburg, Germany) and D. Hodgson (University of Warwick, UK) for provision of strains and phage. This work was supported by the Ministry for Agriculture, Fisheries and Food (K.C.H.) and the Royal Society (S. J.F.).

\section{REFERENCES}

Aldea, M., Hernandez Chico, C., de la Campa, A. G., Kushner, S. R. \& Vicente, M. (1988). Identification, cloning, and expression of bolA, an ftsZ-dependent morphogene of Escherichia coli. J Bacteriol 170, 5169-5176.

Antelmann, H., Bernhardt, J., Schmid, R., Mach, H., Völker, U. \& Hecker, M. (1997). First steps from a two-dimensional protein index towards a response-regulation map for Bacillus subtilis. Electrophoresis 18, 1451-1463.

Beck von Bodman, S., Hayman, G. T. \& Farrand, S. K. (1992). Opine catabolism and conjugal transfer of the nopaline $\mathrm{Ti}$ plasmid pTiC58 are coordinately regulated by a single repressor. Proc Natl Acad Sci US A 89, 643-647.

Becker, L. A., Çetin, M. S., Hutkins, R. W. \& Benson, A. K. (1998). Identification of the gene encoding the alternative sigma factor $\sigma^{\mathrm{B}}$ from Listeria monocytogenes and its role in osmotolerance. J Bacteriol 180, 4547-4554.

Beers, R. F. \& Sizer, I. W. (1952). A spectrophotometric method for measuring the breakdown of hydrogen peroxide by catalase. $J$ Biol Chem 195, 133-140.

Behari, J. \& Youngman, P. (1998). Regulation of hly expression in Listeria monocytogenes by carbon sources and $\mathrm{pH}$ occurs through separate mechanisms mediated by PrfA. Infect Immun 66, $3635-3642$.

Bernhardt, J., Völker, U., Völker, A., Antelmann, H., Schmid, R., Mach, H. \& Hecker, M. (1997). Specific and general stress proteins in Bacillus subtilis - a two-dimensional protein electrophoresis study. Microbiology 143, 999-1017.

Böckmann, R., Dickneite, C., Middendorf, B., Goebel, W. \& Sokolovic, Z. (1996). Specific binding of the Listeria monocytogenes transcriptional regulator PrfA to target sequences requires additional factor(s) and is influenced by iron. Mol Microbiol 22, 643-653.

Bolton, L. F. \& Frank, J. F. (1999). Simple method to observe the adaptive response of Listeria monocytogenes in food. Lett Appl Microbiol 29, 350-353.

Camilli, A., Portnoy, D. A. \& Youngman, P. (1990). Insertional mutagenesis of Listeria monocytogenes with a novel Tn917 derivative that allows direct cloning of DNA flanking transposon insertions. J Bacteriol 172, 3738-3744.

Casadei, M. A., Esteves de Matos, R., Harrison, S. T. \& Gaze, J. E. (1998). Heat resistance of Listeria monocytogenes in dairy products as affected by the growth medium. J Appl Microbiol 84, 234-239.

Cashel, M., Gentry, D. R., Hernandez, V. J. \& Vinella, D. (1996). The stringent response. In Escherichia coli and Salmonella: Cellular and Molecular Biology, 2nd edn, pp. 1458-1496. Edited by F. C. Neidhardt and others. Washington, DC: American Society for Microbiology.

Chan, P. F., Foster, S. J., Ingham, E. \& Clements, M. O. (1998). The Staphylococcus aureus alternative sigma factor $\sigma^{\mathrm{B}}$ controls the environmental stress response but not starvation survival or pathogenicity in a mouse abscess model. J Bacteriol 180, 6082-6089.

Clements, M. O., Watson, S. P. \& Foster, S. J. (1999). Characterisation of the major superoxide dismutase of Staphylococcus aureus and its role in starvation survival, stress resistance, and pathogenicity. J Bacteriol 181, 3898-3903.

Dallmier, A. W. \& Martin, S. E. (1988). Catalase and superoxide dismutase activities after heat injury of Listeria monocytogenes. Appl Environ Microbiol 54, 581-582.

Dallmier, A. W. \& Martin, S. E. (1990). Catalase, superoxide dismutase, and hemolysin activities and heat susceptibility of Listeria monocytogenes after growth in media containing sodium chloride. Appl Environ Microbiol 56, 2807-2810.

Derré, I., Rapoport, G. \& Msadek, T. (1999). CtsR, a novel regulator of stress and heat shock response, controls $c l p$ and molecular chaperone gene expression in gram-positive bacteria. Mol Microbiol 31, 117-131.

Dukan, S. \& Nyström, T. (1998). Bacterial senescence: stasis results in increased and differential oxidation of cytoplasmic proteins leading to developmental induction of the heat shock regulon. Genes Dev 12, 3431-3441.

Engelmann, S. \& Hecker, M. (1996). Impaired oxidative stress resistance of Bacillus subtilis sigB mutants and the role of katA and katE. FEMS Microbiol Lett 145, 63-69.

Farber, J. M. \& Peterkin, P. I. (1991). Listeria monocytogenes, a food-borne pathogen. Microbiol Rev 55, 476-511.

Foster, J. W. \& Spector, M. P. (1995). How Salmonella survive against the odds. Annu Rev Microbiol 49, 145-174.

Gahan, C. G. M., O'Driscoll, B. \& Hill, C. (1996). Acid adaptation of Listeria monocytogenes can enhance survival in acidic foods and during milk fermentation. Appl Environ Microbiol 62, 3128-3132. Hanawa, T., Yamamoto, T. \& Kamiya, S. (1995). Listeria mono- 
cytogenes can grow in macrophages without the aid of proteins induced by environmental stresses. Infect Immun 63, 4595-4599.

Hartke, A., Bouche, S., Gansel, X., Boutibonnes, P. \& Auffray, Y. (1994). Starvation-induced stress resistance in Lactococcus lactis subsp. lactis IL1403. Appl Environ Microbiol. 60, 3474-3478.

Hecker, M. \& Völker, U. (1998). Non-specific, general and multiple stress resistance of growth-restricted Bacillus subtilis cells by the expression of the $\sigma^{\mathrm{B}}$ regulon. Mol Microbiol 29, 1129-1136.

Hengge-Aronis, R. (1996). Regulation of gene expression during entry to stationary phase. In Escherichia coli and Salmonella: Cellular and Molecular Biology, 2nd edn, pp. 1497-1512. Edited by F. C. Neidhardt and others. Washington, DC: American Society for Microbiology.

Hodgson, D. A. (2000). Generalised transduction of serotype 1/2 and serotype $4 \mathrm{~b}$ strains of Listeria monocytogenes. Mol Microbiol 35, 312-323.

Jenkins, D. E., Schultz, J. E. \& Matin, A. (1988). Starvationinduced cross protection against heat or $\mathrm{H}_{2} \mathrm{O}_{2}$ challenge in Escherichia coli. J Bacteriol 170, 3910-3914.

Kjelleberg, S., Albertson, N., Flardh, K., Holmquist, L., JouperJaan, A., Marouga, J., Ostling, J., Svenblad, B. \& Wiechart, D. (1993). How do non-differentiating bacteria adapt to starvation? Antonie Leeuwenhoek 63, 333-341.

Kolter, R., Siegele, D. A. \& Tormo, A. (1993). The stationary phase of the bacterial life cycle. Annu Rev Microbiol 47, 855-874.

Kullik, I. \& Giachino, P. (1997). The alternative sigma factor $\sigma^{\mathrm{B}}$ in Staphylococcus aureus: regulation of the sigB operon in response to growth phase and heat shock. Arch Microbiol 167, 151-159.

Lampidis, R., Gross, R., Sokolovic, Z., Goebel, W. \& Kreft, J. (1994). The virulence regulator protein of Listeria ivanovii is highly homologous to PrfA from Listeria monocytogenes and both belong to the CRP-FNR family of transcription regulators. Mol Microbiol 13, 141-151.

Lange, R. \& Hengge-Aronis, R. (1991). Growth phase-regulated expression of bolA and morphology of stationary-phase Escherichia coli cells are controlled by the novel sigma factor sigma S. J Bacteriol 173, 4474-4481.

Leimeister-Wächter, M., Domann, E. \& Chakraborty, T. (1992). The expression of virulence genes in Listeria monocytogenes is thermoregulated. J Bacteriol 174, 947-952.

Lou, W. Q. \& Yousef, A. E. (1996). Resistance of Listeria monocytogenes to heat after adaptation to environmental stresses. $J$ Food Prot 59, 465-471.

Matin, A. (1991). The molecular basis of carbon-starvationinduced general resistance in Escherichia coli. Mol Microbiol 5, 3-10.

Mengaud, J., Dramsi, S., Gouin, E., Vazquez-Boland, J.-A., Milon, G. \& Cossart, P. (1991). Pleiotropic control of Listeria monocytogenes virulence factors by a gene that is autoregulated. Mol Microbiol 5, 2273-2283.

Morton, D. S. \& Oliver, J. D. (1994). Induction of carbon starvation-induced proteins in Vibrio vulnificus. Appl Environ Microbiol 60, 3653-3659.

Mukamolova, G. L., Yanopolskaya, N. D., Votyakova, T. V., Popov, V. I., Kaprelyants, A. S. \& Kell, D. B. (1995). Biochemical changes accompanying the long-term starvation of Micrococcus luteus cells in spent growth medium. Arch Microbiol 163, 373-379.
Nyström, T. (1999). Starvation, cessation of growth and bacterial ageing. Curr Opin Microbiol 2, 214-219.

Nyström, T., Olsson, R. M. \& Kjelleberg, S. (1992). Survival, stress resistance and alterations in protein expression in the marine Vibrio sp. strain S14 during starvation for different individual nutrients. Appl Environ Microbiol 58, 55-65.

O'Driscoll, B., Gahan, C. G. M. \& Hill, C. (1996). Adaptive acid tolerance in Listeria monocytogenes: isolation of an acid tolerant mutant which demonstrates increased virulence. Appl Environ Microbiol 62, 1693-1698.

Reeve, C. A., Amy, P. S. \& Matin, A. (1984). Role of protein synthesis in the survival of carbon-starved Escherichia coli K-12. J Bacteriol 160, 1041-1046.

Ripio, M.-T., Vazquez-Boland, J.-A., Vega, Y., Nair, S. \& Berche, P. (1998). Evidence for expressional crosstalk between the central virulence factor PrfA and the stress response mediator $\mathrm{ClpC}$ in Listeria monocytogenes. FEMS Microbiol Lett 158, 45-50.

Rouquette, C., Ripio, M.-T., Pellegrini, E., Bolla, J.-M., Tascon, R. I., Vazquez-Boland, J.-A. \& Berche, P. (1996). Identification of a ClpC ATPase required for stress tolerance and in vivo survival of Listeria monocytogenes. Mol Microbiol 21, 977-987.

Sambrook, J., Fritsch, E. F. \& Maniatis, T. (1989). Molecular Cloning: a Laboratory Manual, 2nd edn. Cold Spring Harbor, NY : Cold Spring Harbor Laboratory.

Seymour, R. L., Khan, M. A. \& Spector, M. P. (1996). Essential roles of core starvation stress response loci in carbon-starvationinducible cross-resistance and hydrogen peroxide-inducible adaptive resistance to oxidative challenge in Salmonella typhimurium. Mol Microbiol 20, 497-505.

Siegele, D. A., Almiron, M. \& Kolter, R. (1993). Approaches to the study of survival and death in stationary phase Escherichia coli. In Starvation in Bacteria, pp. 151-167. Edited by S. Kjelleberg. New York: Plenum.

Spector, M. P. \& Cubitt, C. L. (1992). Starvation-inducible loci of Salmonella typhimurium-regulation and roles in starvation survival. Mol Microbiol 6, 1467-1476.

Trivett, T. L. \& Meyer, E. A. (1971). Citrate cycle and related metabolism of Listeria monocytogenes. J Bacteriol 107, 770-779.

Völker, U., Maul, B. \& Hecker, M. (1999). Expression of the $\sigma^{\mathrm{B}}$ dependent general stress regulon confers multiple stress resistance in Bacillus subtilis. J Bacteriol 181, 3942-3948.

Watson, S. P., Clements, M. O. \& Foster, S. J. (1998a). Characterisation of the starvation-survival response of Staphylococcus aureus. J Bacteriol 180, 1750-1758.

Watson, S. P., Antonio, M. \& Foster, S. J. (1998b). Isolation and characterisation of Staphylococcus aureus starvation-induced, stationary-phase mutants defective in survival or recovery. Microbiology 144, 3159-3169.

Wiedmann, M., Arvik, T. J., Hurley, R. J. \& Boor, K. J. (1998). General stress transcription factor $\sigma^{\mathrm{B}}$ and its role in acid tolerance and virulence of Listeria monocytogenes. J Bacteriol 180, 3650-3656.

Wuenscher, M. D., Kohler, S., Bubert, A., Gerike, U. \& Goebel, W. (1993). The iap gene of Listeria monocytogenes is essential for cell viability, and its gene product, p60, has bacteriolytic activity. $J$ Bacteriol 175, 3491-3501.

Received 28 February 2001; revised 27 April 2001; accepted 8 May 2001. 